\title{
Adaptive reuse as a strategy towards conservation of cultural heritage: a literature review
}

\author{
B. Plevoets \& K. Van Cleempoel \\ PHL University College \& Hasselt University, Belgium
}

\begin{abstract}
The paper presents a survey of scholarly literature on the subject of adaptive reuse within the discipline of heritage conservation and architecture. The different theories are compared and classified according to their approach towards adaptive reuse. Three main approaches can be distinguished: typological, technical and architectural strategies. Each approach is discussed separately and an overview of relevant literature is presented in a schematic way. To conclude, we indicate four important gaps in existing theories on adaptive reuse of historic buildings.

Keywords: adaptive reuse, literature review, theory building.
\end{abstract}

\section{Introduction}

Today, working with existing buildings, repairing and restoring them for continued use has become a creative and fascinating challenge within the architectural discipline $[1,2]$. This process of wholeheartedly altering a building is often called 'adaptive reuse' [3]. According to Brooker and Stone, the term 'adaptive reuse' - also called 'remodelling', 'retrofitting', 'conversion', 'adaptation', 'reworking', 'rehabilitation' or 'refurbishment' [3-6] - includes that 'the function is the most obvious change, but other alterations may be made to the building itself such as the circulation route, the orientation, the relationships between spaces; additions may be built and other areas may be demolished' [3]. Moreover, in contemporary conservation theory and practise, adaptive reuse is considered an important strategy towards conservation of cultural heritage $[4,7]$. Although since ancient times, buildings have been altered to fit changed needs and wants in a rather pragmatic way $[1,8]$, while critical 
reflection on the different approaches towards adaptive reuse is rather recent [first publication: 9].

The purpose of this paper is to present an overview of the existing theories on adaptive reuse, seen from the perspective from heritage conservation and architecture through an extensive study of scholarly literature. The different theories are compared and classified according to their approach towards adaptive reuse. Three main approaches can be distinguished: typological, technical and architectural strategies. Each approach is discussed separately and an overview of relevant literature is presented in a schematic way. To conclude, we indicate the gaps in existing theories on adaptive reuse of historic buildings.

\section{Theoretical development}

Altering existing buildings for new functions is not a new phenomenon; in the past, buildings that were structurally secure have been adapted to fit changed needs or new functions without questions or problems. For example during the Renaissance period, classical monuments were transformed for new uses or during the French Revolution religious buildings were transformed for industrial functions or military uses after they had been confiscated and sold [10-12]. These interventions, however, were done in a pragmatic way in many cases without heritage preservation as an intention [8]. Instead, the driving force behind reuse was basically functional and financial [1].

A theoretical approach towards adaptive reuse was only established in the $19^{\text {th }}$ century [13] when Eugène Emmanuel Viollet-le-Duc (1814-1879) recognized adaptive reuse as a way to preserve historic monuments. He argued that "the best way to preserve a building is to find a use for it, and then to satisfy so well the needs dictated by that use that there will never be any further need to make any further changes in the building" [14]. His ideas, however, have been strongly objected by John Ruskin (1819-1900) and his pupil William Morris (18341896) who found it "impossible, as impossible as to raise the dead, to restore anything that has ever been great or beautiful in architecture" and instead of restoration they favoured regular care and maintenance to ensure the preservation of historic buildings [15]. In the early $20^{\text {th }}$ century, the conflict between these opposing theories on adaptive reuse has been discussed by Alois Riegl (18581905) [16]. He ascribes this conflict in theories to the different values their adherences attribute to monuments. Riegl distinguishes different types of values which he generally grouped as commemorative values (including age-value, historical value and intentional commemorative value) as opposed to present-day values (including use-value, art-value and newness-value). By including the usevalue in his assessment of monuments, he recognized reuse of historic buildings as an intrinsic part of modern conservation [17].

During the post-war era, architects aspire to create new buildings which completely break with traditional building. However, as a reaction to the increased demolishment and new construction, a growing interest has been developed in conservation of old buildings of every kind [9]. As such, during the second half of the 20th century architects start to consider working with historic 
buildings an interesting challenge and make it an important aspect of their work, e.g. Carlo Scarpa, Raphaël Moneo, Herzog \& Demeuron. Hence, from the 1970s onwards, adaptive reuse has been a key subject for many conferences on architecture and conservation as for scholarly literature. In May 1972, the Architectural Review published a special issue on this topic [18] which had led three years later in a book with the same title 'New Uses for Old Buildings' [9]. In 1977 two symposia were organised: 'Old into New' held in Glasgow and 'Old and New Architecture: Design Relationship' held in Washington D.C.; both conferences had led to a publication in the years to follow $[5,19]$.

\section{Contemporary theories on adaptive reuse: a literature review}

To get insight in the extent scholarly literature on adaptive reuse, we reviewed, compared and contrasted contemporary literature on the subject (1970s up to the present). We have identified three different approaches: (1) typological, (2) technical and (3) architectural strategies. First, these three approaches are discussed independently from each other. Some publications present more than one approach; these are discussed within the different paragraphs.

Only studies in the field of heritage conservation and architecture are considered; beside these disciplines, adaptive reuse has also been studied within the fields of urban regeneration, engineering, sustainability and economy [20] but these publications are not part of this research. Moreover, only international literature is considered. As heritage conservation is often organised on national or local level, a wide variety of regional literature is available but these are not reviewed within the scope of this paper.

\subsection{Typological approach}

The first publication on adaptive reuse 'New uses for old buildings' came from Cantacuzino [9]. The introductory essay explains the history of adaptive reuse and its role within current conservation practise and is followed by a selection of examples from all over the world, which are organised according to their building type before conversion. In 1989, the author made a new publication on the subject, also including an introductory essay and a range of examples. This time, six different building categories are presented which each contain several building types. Several authors followed this approach of presenting an introductory essay followed by case studies which are organised according to the building category or building type of the host space [12, 21]. Douglas [22] also organises part of his extensive work on building adaptation according to the typology of the host space, although, the variety of building types discussed are limited. For each type, there are only a few new uses discussed but no supportive case studies are included; instead, he focuses on the reason of redundancy and the difficulties and opportunities towards reuse of each typology. Furthermore, numerous studies have approached the reuse of one specific building type, e.g. religious buildings [among others: 23-25] or industrial buildings [among others: 
158 Structural Repairs and Maintenance of Heritage Architecture XII

Table 1: Classification into building typologies.

\begin{tabular}{|c|c|}
\hline TYPOLOGY & LITERATURE \\
\hline \multicolumn{2}{|c|}{ Industrial buildings } \\
\hline Factory & {$[21,22,26-28,36]$} \\
\hline Warehouse & {$[9,21,22,27,28,36]$} \\
\hline Barn & {$[9,12,22,27,29,36]$} \\
\hline Granary & {$[9,12,21,36]$} \\
\hline Mills & {$[9,12,21,22,27,36]$} \\
\hline Brewery & {$[9,21,27,36]$} \\
\hline Malting & {$[9,12,21,27]$} \\
\hline Mining site & {$[27]$} \\
\hline Railway station & {$[9,21,27,36]$} \\
\hline \multicolumn{2}{|c|}{ Religious buildings } \\
\hline Church \& Chapel & {$[9,12,21-25,36]$} \\
\hline Convent & {$[9,36]$} \\
\hline \multicolumn{2}{|l|}{ Beguinage } \\
\hline \multicolumn{2}{|l|}{ Presbytery } \\
\hline \multicolumn{2}{|c|}{ (Semi-)public buildings } \\
\hline City Hall & {$[9,36]$} \\
\hline Museum & {$[22]$} \\
\hline School & {$[9,12,21,28,36,37]$} \\
\hline Hospital & {$[9,21,22,36]$} \\
\hline Observatory & {$[36]$} \\
\hline Court House & {$[36]$} \\
\hline Office & {$[12,21,22]$} \\
\hline Library & [21] \\
\hline Theatre & [21] \\
\hline Hotel \& Hostel & [12] \\
\hline Post Office & [22] \\
\hline \multicolumn{2}{|c|}{ Residential buildings } \\
\hline Castle & {$[21,36]$} \\
\hline Country house & {$[9,12,21,36]$} \\
\hline Farm & {$[12,21,22,36]$} \\
\hline Town house & {$[9,12,21,36]$} \\
\hline \multicolumn{2}{|c|}{ Military buildings } \\
\hline Fortress & {$[9,21]$} \\
\hline Barrack & {$[9,21]$} \\
\hline Gate & [9] \\
\hline \multicolumn{2}{|c|}{ Commercial buildings } \\
\hline \multicolumn{2}{|l|}{ Craft shop } \\
\hline Department store & {$[21,28]$} \\
\hline Exchange & {$[9,36]$} \\
\hline Bank & {$[36]$} \\
\hline Market & {$[21,36]$} \\
\hline \multicolumn{2}{|l|}{ Boutique } \\
\hline Passage & [38] \\
\hline
\end{tabular}


26-28]. Table 1 presents a classification of heritage categories and typologies, indicating the different sources dealing with each of the building types.

Fisher [29] and Powell [1] applied a typological approach in a slightly different way by organizing a selection of cases according to their contemporary use (the program). As such there emphasis is on contemporary architecture and interventions instead of the historical aspect of the building. Table 2 indicates which sources have dealt with the distinct programs.

Table 2: $\quad$ Classification into architectural programs.

\begin{tabular}{|c|c|}
\hline PROGRAM & LITERATURE \\
\hline Dwelling & {$[1,9,21,29,36]$} \\
\hline \multicolumn{2}{|c|}{ Culture } \\
\hline Museum \& Exhibition & {$[1,9,21,29,36]$} \\
\hline Library & {$[1,21,29]$} \\
\hline Theatre & {$[1,9,21,36]$} \\
\hline Education & {$[1,9,21,29,36]$} \\
\hline Retail & {$[1,9,21,36]$} \\
\hline Office & {$[1,9,21,29,36]$} \\
\hline Leisure & {$[9,21]$} \\
\hline Care & {$[21,36]$} \\
\hline Industry & {$[21]$} \\
\hline Religious & [21] \\
\hline Military & {$[21]$} \\
\hline Mixed-use development & {$[9,29,36]$} \\
\hline
\end{tabular}

\subsection{Technical approach}

Some authors have approached building adaptation as primarily a technical question. As such, some 'guidebooks' have been developed on how to adapt a building to allow a new function. Highfield published in 1987 a small booklet 'The rehabilitation and re-use of old buildings' in which he first expounds the advantages of rehabilitation, making a distinction between domestic and nondomestic buildings; secondly, he includes a technical chapter in which he discusses the improvement of fire resistance, thermal performance, acoustic performance, prevention of damp penetration, condensation and timber decay; to conclude he presents some case studies which he describes primarily from a technical point of view [30]. In the next decennia, he published several 'updates' of this book, following the same concept $[31,32]$ but discussing an increased number of technical issues (see table 3). Moreover, a major extent of the work of Douglas [22] deals with technical aspects of reuse. Although the implications of protection of a building are discussed both by Highfield as by Douglas, they seem to approach the host space merely as a shell or container and therefore give little attention to the conservation and heritage aspects. Contrary, several other authors that focus on technical aspects of reuse (see table 3), do stress the importance of an interdisciplinary approach towards reuse of historic buildings, including issues of conservation, architecture, planning and engineering $[33,34]$. 
Table 3: $\quad$ Technical issues on adaptive reuse

\begin{tabular}{|c|c|}
\hline UPGRADING & LITERATURE \\
\hline \multicolumn{2}{|c|}{$\begin{array}{ll}\text { Loadbearing structure } \\
\end{array}$} \\
\hline $\begin{array}{c}\text { Frames (timber structures, iron } \\
\text { structures,...) }\end{array}$ & {$[22,30,31,33,34]$} \\
\hline Floors & {$[22,30,31,33,34]$} \\
\hline Walls & {$[22,33,34]$} \\
\hline Roofs & {$[22,33,34]$} \\
\hline Underpinning & {$[22,31,34]$} \\
\hline Heavy-lifting & {$[31,34]$} \\
\hline \multicolumn{2}{|c|}{ Building envelope } \\
\hline Internal surfaces & {$[30,31]$} \\
\hline Introduction of new floors & {$[22,31]$} \\
\hline Façade & {$[31,39]$} \\
\hline Accessibility and circulation & {$[22,31,34]$} \\
\hline \multicolumn{2}{|c|}{ Comfort, Safety and Energy Efficiency } \\
\hline Fire-resistance & {$[30,31,33,34]$} \\
\hline Thermal performance & {$[22,30,31,33,34]$} \\
\hline Acoustic performance & {$[30,31,33]$} \\
\hline Preventing moisture and dampness & {$[22,30,31,34]$} \\
\hline Indoor air quality & {$[22,34]$} \\
\hline
\end{tabular}

\subsection{Strategic approach}

The strategic approach focuses on the process and strategies applied for converting significant buildings. Machado in his essay "Architecture as Palimpsest' presents what he calls 'some pre-theoretical "suggestive material" that could be developed as concepts to consider what is specific to remodelling' [4]. He considers a series of metaphors to suggest different possible ways of thinking about remodelling. Robert [35], although he does not explicitly refer to Machado's article, also uses the metaphor of the palimpsest to explain the concept of conversion. He presents seven concepts of conversion which he recognizes in outstanding examples of architectural conversions within a wide span of history - he gives examples from ancient times up to the postmodern era: (1) building within, (2) building over, (3) building around, (4) building alongside, (5) recycling materials or vestiges, (6) adapting to a new function and (7) building in the style of. Each of these concepts refers to a specific physical intervention.

Also Brooker and Stone [3] defined different design strategies for building reuse by looking at exemplary cases of contemporary conversions. They came to three strategies being (1) intervention, (2) insertion and (3) installation. Brooker and Stone's approach also start from the physical intervention but their focus is on the affective aspect of each adaptation. For them, the most important and meaningful factor in adaptive reuse is the original building. Jäger [40] presents a very similar approach presenting a selection of case studies classified according to the applied strategy towards the existing fabric, being (1) addition, 
(2) transformation or (3) conversion. The cases are selected based on their architectural quality and originality. Cramer and Breitling [41] make a distinction between 'design strategies' and 'architectonic expressions' whereby they describe design strategies as physical interventions and alterations to the building and architectonic expressions as the aesthetic qualities of the intervention. This distinction, however, is not very sharp and the illustrative examples could be interpreted variously. The strategies defined by the different authors in many cases overlap; figure 1 presents the author's understanding of the analogy between the defined strategies.

\begin{tabular}{|c|c|c|c|c|}
\hline \multicolumn{4}{|c|}{ Design Strategies } & $\begin{array}{l}\text { Architectonic } \\
\text { Expressions }\end{array}$ \\
\hline Robert 1989 & $\begin{array}{l}\text { Brooker \& } \\
\text { Stone } 2004\end{array}$ & Jäger 2010 & \multicolumn{2}{|c|}{ Cramer \& Breitling 2007} \\
\hline Building within & Insertion & Transformation & Modernisation & Correspondence \\
\hline \multicolumn{5}{|l|}{ Building over } \\
\hline $\begin{array}{l}\text { Building } \\
\text { around }\end{array}$ & \multirow{3}{*}{ Intervention } & Addition & & \multirow{3}{*}{ Unification } \\
\hline $\begin{array}{l}\text { Building } \\
\text { alongside }\end{array}$ & & & Adaptation & \\
\hline \multirow{2}{*}{$\begin{array}{l}\text { Adapting to a } \\
\text { new function }\end{array}$} & & Conversion & & \\
\hline & Installation & & & $\begin{array}{c}\text { Junction and } \\
\text { delineation }\end{array}$ \\
\hline $\begin{array}{l}\text { Building in the } \\
\text { style of }\end{array}$ & & & Replacement & \\
\hline $\begin{array}{l}\text { Recycling } \\
\text { materials of } \\
\text { vestiges }\end{array}$ & & & $\begin{array}{l}\text { Corrective } \\
\text { maintenance }\end{array}$ & \\
\hline
\end{tabular}

Figure 1: Analogy between described strategies towards adaptive reuse.

\section{Conclusion}

Within our review of literature on adaptive reuse we have distinguished three contemporary approaches: the typological approach, the technical approach and the strategic approach. As such this literature review shows, firstly, the variety of the existing work on adaptive reuse, the overlap between different theories and the gaps within current knowledge. Concerning the typological approach, table 1 indicates which building types have received major attention (e.g. industrial buildings, residential buildings and churches) as well as those which have been researched in a more limited extent (e.g. religious buildings others than churches, military buildings and commercial buildings). Equally, table 2 presents the programs which have been extensively researched (e.g. cultural and educational programs), and those for which there is still room for further study (e.g. care). For the technical approach we indicate which publications deal with specific technical issues, as presented in table 3. However, as stated by Giebeler et 
al. [33] the available standard works on construction are still particularly relevant in relation to adaptation of existing buildings. As to the strategic approach, although each author has presented an individual description of the architectural strategies towards reuse, we noticed a strong overlap between the categories presented by the different authors (see figure 1).

Secondly although several authors recognize adaptive reuse as an interdisciplinary task $[33,41]$, existing studies are mainly drawn from one specific perspective, such as conservation [19], architecture [1, 35, 40], interior architecture [3] or engineering [31,33] and do often not aim to reach an interdisciplinary public [except for 41].

Thirdly, an approach which seemed limitedly present is a theoretical approach which compares and contrasts different historic theories on architecture and conservation within the framework of adaptive reuse. An exception, however, is Scott [42] who explores the theories of Ruskin, and Viollet-le-Duc in relation to reuse.

Finally, we have noticed that many authors do not, or only limitedly, deal with the 'meaning' of the building to be reused, the genius loci, when describing the process of adaptive reuse. Although studies classified under the strategic approach generally deal more profoundly with the genius loci than studies that follow the typological or technical approach. The most remarkable example comes from Brooker [43] who studied in particular the transformation of buildings which history or narrative is 'contaminated' by a previous use that is disagreeable or objectionable. He suggests several approaches to use this contamination as a starting point for alteration. But modern conservation is rooted in values [44] so assessment of these values should be the basis for each rehabilitation project of a significant building or site. Owners and developers, however, are often primarily interested in the socio-economic values of the building; especially for buildings which are not protected as a monument this may be a threat towards preservation of the 'soft values' which encompass historical, sociological, psychological, artistic, other cultural and even moral and religious sub-functions [45].

\section{References}

[1] Powell, K., Architecture reborn. Converting old buildings for new uses, Rizzoli international publications, inc.: New York, 1999.

[2] Schittich, C. (ed.), Creative Conversions, Building in Existing Fabric Refurbishment Extensions New Design, Birkhäuser: Basel, p. 9, 2003.

[3] Brooker, G. \& Stone, S., Re-readings. Interior architecture and the design principles of remodelling existing buildings. RIBA Enterprises: London, 2004.

[4] Machado, R., Old buildings as palimpsest. Towards a theory of remodeling, Progressive Architecture, 11, pp. 46-49, 1976.

[5] Markus, T., Building Conversion and Rehabilitation, Butterworth: London, 1979. 
[6] Giebeler, G., Definitions, Refurbishment Manual: Maintenance, Conversions, Extensions, ed. J. Liese, Birkenhauser: Basel, Boston \& Berlin, pp. 10-15, 2009.

[7] Jessen, J. \& Schneider, J., Conversions - the new normal, Building in Existing Fabric - Refurbishment Extensions New Design, Birkhäuser: Basel, pp. $11-21,2003$.

[8] Pérez de Arce, R., Urban Transformations \& The Architecture of Additions, Architectural Design, 4, pp. 237-266, 1978.

[9] Cantacuzino, S. , New uses for old buildings, Architectural press : London, 1975.

[10] Linters, A., Réflechissez avant d'agir, Revue du Patrimoine Culturel Européen, pp. 4-12, 2006.

[11] Dubois, M., Hergebruik van gebouwen in Europees perspectief, kunsttijdschrift Vlaanderen. Het hergebruik van gebouwen., 271, pp. 121127, 1998.

[12] Cunnington, P. , Change of Use: the Conversion of Old Buildings. Alpha Books: London, 1988.

[13] Plevoets, B. \& Van Cleempoel, K., Theoretical development on adaptive reuse: a historic overview, in process.

[14] Viollet-le-Duc, E., The Foundations of Architecture. Selections from the Dictionnaire raisonné, George Braziller: New York, 1990 [1854].

[15] Ruskin, J., The Seven Lamps of Architecture. Smith, Elder: Londen, 1849.

[16] Riegl, A., Der Moderne Denkmalkultus: Sein Wesen und seine Entstehung, Gesammelte Aufsätze, ed Dr. Benno Filser Verlag: Augsburg-Wien, pp. 144-193, 1928 [1903].

[17] Plevoets, B. \& Van Cleempoel, K., Adaptive reuse within the retail design discipline: exploring the concept of authenticity. Proc. Of the First International Congress on Architectural Design, Teaching and Research, Bari, Italy, Mai 3-7, 2011, accepted for publication.

[18] Cantacuzino, S., New uses for old buildings, Architectural Review, CLI, pp. 262-324, 1972.

[19] National Trust for Historic Preservation, Ed., Old \& New Architecture: Design Relationships. Washington D.C.: The Preservation Press, 1980.

[20] Bullen P. \& Love, P., The rhetoric of adaptive reuse or reality of demolishion: Views from the field., Cities, 27, pp. 215-224, 2010.

[21] Latham, D., Creative re-use of buildings vol. 1\&2, Donhead: Shaftesbury, 2000.

[22] Douglas, J., Building Adaptation, 2 ed., Elsevier: Oxford, 2006.

[23] Alavedra, I., (ed.), Converted Churches. Tectum Publishers: Antwerp, 2007.

[24] Morisset, L., Noppen, L. \& Coomans, T. (eds.), Quel avenir pour quelles églises? What future for which churches? Presses de l'université du Québec: Québec, 2005.

[25] English Heritage, New Work in Historic Places of Worship. English Heritage: London, 2003. 
[26] Bordage F. \& Faure, F., The factories. Conversions for urban culture. TransEuropeHalles, Birkhäuser-Publishers for Architecture: Basel, 2002.

[27] Stratton, M. (ed.), Industrial Buildings Conservation and Regeneration, Taylor and Francis: London, 2000.

[28] Henehan, D., Woodson, D., \& Culbert, S., Building Change-of-Use. Renovation, Adapting, and Altering Comercial, Institutional, and Industrial Properties. The McGraw-Hill Companies: New York, 2004.

[29] Fisher, A., New life in old buildings. Verlag: Stuttgart \& Zurich, 1992.

[30] Highfield, D., The rehabilitation and re-use of old buildings, Spon Press (Taylor and Francis): London \& New York, 1987.

[31] Gorse, C. \& Highfield, D. Refurbishment and Upgrading of Buildings. Spon Press (Taylor and Francis): London \& New York, 2009.

[32] Highfield, D. , Refurbishment and Upgrading of Existing Buildings. Spon Press (Taylor and Francis): London \& New York, 2000.

[33] Giebeler, G., Fisch, R., Krause, H., Musso, F., Petzinka, K., \& Rudolphi, A., Refurbishment Manual: Maintenance, Conversions, Extensions. Birkenhauser: Basel, Boston, Berlin, 2009.

[34] Rabun, J. \& Kelso, R., Building Evaluation for Adaptive Reuse and Preservation. John Wiley \& Sons: Hoboken, New Jersey, 2009.

[35] Robert, P., Adaptations. New Uses for Old Buildings. Editions du Moniteur: Paris, 1989.

[36] Cantacuzino, S., Re/Architecture: Old Buildings/New Uses. Thames and Hudson: London, 1989.

[37] English Heritage, The Future of Historic School Buildings, English Heritage: London, 2005.

[38] MacKeith, M., The History and Conservation of Shopping Arcades. Mansell Publishing Limited: London and New York, 1986.

[39] Highfield, D. , The construction of new buildings behind historic façades. Spon Press (Taylor and Francis): London \& New York, 1991.

[40] Jäger, F. (ed.), Old \& New. design Manual for Revitalizing Existing Buildings. Birkhäuser: Basel, 2010.

[41] Cramer, J. \& Breitling, S., Architecture in existing fabric. Birkhäuser: Berlin, 2007.

[42] Scott, F., On Altering Architecture. Routledge: London, 2008.

[43] Brooker, G., Infected Interiors:Remodelling Conteminated Buildings. Proc. Of the Living in the Past: Histories, Heritage and the Interior. 6th Modern Interiors Research Centre Conference, 14 \& 15 May Kingston University London, 2009.

[44] ICOMOS, The Nara Document on Authenticity in Relation to the World Heritage Convention. ICOMOS: Nara, 1-6 November 1994.

[45] Van Hooydonck, E., Soft Values of Seaports. A Plea for Soft Values Management by Port Authorities, Proc. of the European Sea Ports Organisation's Annual Conference, Stockholm, 2006. 